\title{
PERFIL DOS ÓBITOS FETAIS E ÓBITOS NEONATAIS PRECOCES NA REGIÃO DE SAÚDE DE LAGUNA (2010-2014)
}

Jully Anne Wiggers Duessmann Enfermeira, Centro Universitário Barriga Verde, jullyannew_17@hotmail.com Silvia Salvador do Prado Mestra, Centro Universitário Barriga Verde, sisaprado@yahoo.com.br Ana Paula Bazo Doutora, Centro Universitário Barriga Verde, apbazo@gmail.com Sirli Resin Enfermeira, Centro Universitário Barriga Verde, siliresin@gmail.com Elias Wiggers Neto Profissional de Educação Física, Universidade do Extremo Sul Catarinense, neto_wiggers@hotmaill.com Suelen Mateus Enfermeira, Centro Universitário Barriga Verde, suelen.mateus@hotmail.com Ranusia Adelia Talamini Garcia Enfermeira, Centro Universitário Barriga Verde, ranusiaatalaimini@hotmail.com Karla Pickler Cunha Enfermeira, Centro Universitário Barriga Verde, jamille.karla@gmail.com 


\section{RESUMO}

O conhecimento sobre os nascimentos, óbitos fetais e óbitos até o sétimo dia de vida, em um determinado tempo e região, é fundamental para elaboração de indicadores demográficos e epidemiológicos, a fim de que, a partir desses dados sobre a realidade daquela comunidade, estratégias efetivas de melhorias das condiçôes de saúde de uma determinada população possam ser planejadas e implementadas. O objetivo geral é identificar o perfil dos óbitos fetais e de recém-nascidos (do primeiro ao sexto dia de vida) na regiáo de saúde de Laguna (2010-2014). Para isso, o estudo configura-se como estudo exploratório e descritivo, com abordagem quantitativa. Para o local de coleta de dados, foram utilizados dois bancos de dados: o TABNET, do Sistema de informaçóes sobre mortalidade (SIM), na página da Diretoria de Vigilância Epidemiológica de Santa Catarina (DIVE-SC), e o banco de dados do Departamento de Informática do Sistema Único de Saúde (DATASUS), do Ministério da Saúde, onde foram coletadas informações referentes aos óbitos fetais. Para tabulação e cálculo dos dados, foi utilizado o Excel, versão 2010. Sobre a amostra, foram 18 municípios que compóem a regiấo de saúde de Laguna, em Santa Catarina. Em relação aos óbitos fetais (OF) da regiâo de saúde de Laguna, entre 2010 e 2014, foram 138, com coeficiente de natimortalidade médio de 6,44/1000. Em números absolutos, o município de Tubarão é o maior, com $31 \mathrm{OF}$. Com o uso do coeficiente de natimortalidade, o município de Tubarão fica com a $13^{a}$ posição, cuja média é de 4,98/1000 nascidos vivos (NV). Em 2010, o maior índice de natimortalidade foi Imaruí (com 21,98/1000 NV); em 2011, Armazém (com 37,03/1000 NV); em 2011, Pedras Grandes (com 31,25/1000 NV); em 2012, Grão Pará (com 13,69/1000); em 2013, Pedras Grandes (com 31,25/1000 NV); em 2014, São Martinho (com 27,03/1000 NV). Dois municípios não apresentaram óbitos fetais durante o período da pesquisa: Rio Fortuna e Santa Rosa de Lima. Na coleta das variáveis previamente selecionadas dos óbitos fetais, a análise considerou os anos de 2010 a 2013, pois o ano de 2014 ainda não está disponível no TABNET, do Ministério da Saúde. Assim, para as variáveis, foram considerados 101 óbitos fetais. Em relação ao sexo dos óbitos fetais, 55,12\% (n=43) foram óbitos fetais 
do sexo masculino, 44,87\% ( $n=35)$ do sexo feminino e $29,48 \%(n=23)$ de sexo indeterminado. Em relação ao peso, $66 \%$ dos óbitos fetais apresentavam baixo peso, $12 \%$ apresentavam peso ignorado, $11 \%$ peso insuficiente, $8 \%$ peso normal e 3\% eram macrossômicos. Quanto ao tipo de parto dos óbitos fetais, 63,36\% $(\mathrm{n}=64)$ foram partos vaginais e 34,65\% $(\mathrm{n}=35)$ foram partos cesáreos, enquanto $1,98 \%(n=2)$ não foi informado. Em relação aos óbitos neonatais precoces (recém-nascidos até o sexto dia de vida), a região de saúde de Laguna, no período selecionado, teve 111 óbitos. Com exceção de Pescaria Brava (município novo), todos os municípios apresentaram óbitos neonatais precoces em, ao menos, 1 ano do período selecionado. Imaruí foi o maior em 2010 (com 11,23/1000 NV); São Ludgero em 2011 (com 19,23/1000 NV); Santa Rosa de Lima apresentou um alto coeficiente no ano de 2012 (com 62,50/1000 NV); no ano de 2013, apareceu o município de Gravatal (com 15,74/1000 NV); já em 2014, foi Armazém (com 28,03/1000 NV). Com relação à causa básica de óbito, de acordo com a Classificação Estatística Internacional de Doenças e Problemas Relacionados à Saúde, 10ª Revisão (CID 10), a região de saúde de Laguna teve, nos últimos cinco anos, como causa básica dos óbitos neonatais precoces, um predomínio do desconforto respiratório do recém-nascido (P22.-), com 22 óbitos, seguido da septicemia bacteriana do recém-nascido (P36.-), com 21 óbitos. Em relação à causa Capítulo, o Capítulo XVI, em que estão listadas algumas afecçóes originadas no período neonatal (P00-P96), compreendeu 77,48\% (n=86) dos óbitos neonatais precoces, enquanto $19,82 \%(\mathrm{n}=22)$ dos óbitos corresponderam ao Capítulo XVII, das malformaçóes congênitas, deformidades e anomalias cromossômicas (Q00-Q99). Quanto ao tipo de parto, 36,93\% ( $\mathrm{n}=41)$ nasceram de parto normal, 57,65\% $(\mathrm{n}=64)$ de parto cesáreo e 5,42\% $(\mathrm{n}=6)$ de parto ignorado (BRASIL, 2015; SANTA CATARINA, 2015). Da região de saúde de Laguna, Tubarão, por ser o maior em populaçáo da regiáo em números absolutos, apresentou os maiores números, porém, ao ser empregado os cálculos proporcionais, o município ficou em $12^{\circ}$ e $13^{\circ}$ na classificação. Os melhores indicadores podem ter relação com o fato de o município possuir, em seu território, um hospital de referência à gestação de alto risco, equipado com UTI neonatal. Algumas variáveis tiveram avaliação prejudicada devido ao fato de muitas informaçôes 
constarem como ignoradas. Em relação ao tipo de parto, os partos cesarianos lideram o nascimento de vivos; já nos óbitos fetais, essa realidade é diferente, pois não há mais a preocupação com a saúde do feto, mas com a recuperação materna. Em relação ao peso nos óbitos fetais, percebeu-se um número considerável de fetos com peso adequado para o nascimento ou mesmo grandes. Os recém-nascidos $(\mathrm{RN})$ têm sido acometidos por afecçóes que estão relacionadas ao próprio nascimento do que as malformaçóes ou afecçóes ligadas a problemas da mãe. O que corrobora com as informaçóes apontadas por Leite (1995 apud PEDROSA, 2005) é que, no Brasil, as principais causas de óbitos neonatais são as afecções respiratórias do recém-nascido e as infecções. O Sistema de Informação sobre Mortalidade (SIM) permite a identificação de problemas e, com isso, ações de intervenção no território. Permite conhecer o perfil das mães cujos filhos foram a óbito fetal. Também permite conhecer qual é a causa dos óbitos neonatais precoces. Os dados da pesquisa podem ser utilizados tanto na Saúde Coletiva, para prevenção durante o pré-natal, como nos hospitais, durante o trabalho de parto, parto e cuidados com o RN após o seu nascimento. Com o estudo dos dados do SIM, podem-se perceber as falhas e, a partir delas, buscar por melhorias, como analisar e estudar a assistência ao pré-natal e os fluxos na rede de atenção à saúde.

Palavras-chave: Morte Fetal; Morte Perinatal; Cuidado Pré-Natal.

\section{REFERÊNCIAS}

BRASIL. Ministério da Saúde. Informaçóes de saúde e estatísticas vitais e mortalidade. Disponível em: <http://www2.datasus.gov.br/DATASUS/index. php?area=0205>. Acesso em: 21 ago. 2015.

PEDROSA, L. D. C. O. Avaliaçáo da qualidade das informaçóes oficiais sobre óbitos neonatais precoces em Maceió - Alagoas. 2005. $121 \mathrm{f}$. Dissertação (Mestrado em Saúde da Criança e do Adolescente) - Universidade Federal de Pernambuco, Recife, 2005. 
SANTA CATARINA. Secretaria de Estado da Saúde. Mortalidade infantil - menor de 1 ano. Disponível em: < http://www.saude.sc.gov.br/cgi/tabcgi. exe?inf.def $>$. Acesso em: 20 ago. 2015. 